Check for updates

London

Cite this as: BMJ 2021;374:n2318 http://dx.doi.org/10.1136/bmj.n2318 Published: 21 September 2021

\title{
Compulsory covid vaccination: Loss of care home workers puts beds and care at risk, warn unions and providers
}

Matthew Limb

Social care of elderly and vulnerable people, a sector that currently has an estimated 120 ooo vacancies, could be severely hit as thousands of care home workers face losing their jobs for failing a legal requirement to have covid vaccinations, trade unions and care home providers have warned.

Staffing problems could see some homes having to shut and others offering fewer beds or risk offering substandard care, they said.

Nadra Ahmed, executive chairman of the National Care Association, told The BMJ, "We've heard of providers shutting the doors, they just can't go on any more." She estimated that the loss to the sector resulting from mandatory vaccination could reach 70 ooo workers because of early departures already driven by the policy.

Care home workers in England were supposed to have had their first covid vaccination by midnight on 16 September so that they could meet the government's deadline of 11 November to be fully vaccinated or face being banned from entering care homes.

The government said that all care home workers, and anyone entering a care home, will need to be fully vaccinated, unless they are exempt under the regulation.

England has around 465 ooo care home staff looking after elderly residents. The Department of Health and Social Care said on 16 September that more than $90 \%$ of eligible staff ( 426750 ) had received a first dose and around $84 \%$ (390 649) had had a second dose. ${ }^{1}$ Staff who fail to meet the requirement could be sacked or redeployed. The Care Quality Commission will monitor compliance.

A department spokesperson said, "Our message is clear: vaccines save lives and it is our responsibility to do everything we can to reduce the risk for vulnerable people in care homes.

"Temporarily, those who meet the criteria for a medical exemption will be able to self-certify until we introduce a new system. This will ensure those with medical exemptions can continue working in care homes."

Ahmed said that the full impact on the sector would not be known until after 11 November but that some homes would have to "downsize" and admit fewer residents, which in turn would affect their viability.

A consultation is still under way on making vaccination a condition of deployment for frontline workers in other social care settings and in healthcare. $^{2}$

Ahmed called for a pause and overall review of the policy, saying, "The government should wait for the response to that consultation and bring decisions on both things together."

Christina McAnea, general secretary of the trade union Unison, said that staff who were reluctant to be vaccinated must be offered "reassurance and persuasion, not threats and ultimatums."

A spokesperson for Barchester, which runs around 200 care homes in the UK, said it supported mandatory vaccination and, after positive engagement with staff, had lost less than $1 \%$ of staff who were unwilling to be vaccinated. The spokesperson said, "However, the decision by the government to mandate covid-19 vaccination in care homes and not in the NHS has led to workers leaving employment with providers to go and work in the health services, which has been a drain on staff from the care sector to the NHS."

Governments elsewhere in Europe have also been making vaccination mandatory for care stuff.

According to Reuters, care homes and health centres have suspended around 3000 workers across France for failing to comply with mandatory vaccination.

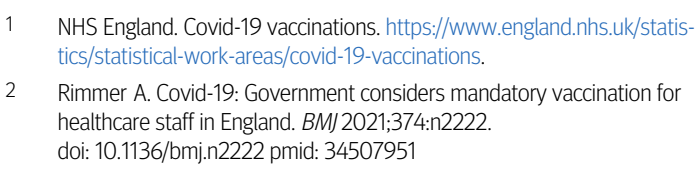

$1 \quad$ NHS England. Covid-19 vaccinations. https://www.england.nhs.uk/statistics/statistical-work-areas/covid-19-vaccinations.

2 Rimmer A. Covid-19: Government considers mandatory vaccination for healthcare staff in England. BMJ2021;374:n2222. doi: 10.1136/bmj.n2222 pmid: 34507951

This article is made freely available for use in accordance with BMJ's website terms and conditions for the duration of the covid-19 pandemic or until otherwise determined by BMJ. You may use, download and print the article for any lawful, non-commercial purpose (including text and data mining) provided that all copyright notices and trade marks are retained. 